\title{
Air Density Climate of Two Caribbean Tropical Islands and Relevance to Wind Power
}

\author{
Xsitaaz Twinkle Chadee and Ricardo Marcus Clarke \\ Environmental Physics Laboratory, Department of Physics, Faculty of Science and Technology, The University of the West Indies, \\ St. Augustine Campus, Trinidad and Tobago \\ Correspondence should be addressed to Xsitaaz Twinkle Chadee; xsitaaz.chadee@sta.uwi.edu
}

Received 16 July 2013; Accepted 25 August 2013

Academic Editors: J. Kaldellis and S. Rehman

Copyright (C) 2013 X. T. Chadee and R. M. Clarke. This is an open access article distributed under the Creative Commons Attribution License, which permits unrestricted use, distribution, and reproduction in any medium, provided the original work is properly cited.

\begin{abstract}
The standard air density of $1.225 \mathrm{~kg} \mathrm{~m}^{-3}$ is often used in determining the energy output of a wind turbine although the energy output is dependent on a site's air density. By using measurements of temperature, dew-point temperature, and pressure, we calculate the monthly air density of moist tropical climates at two sites in the small-island state of Trinidad and Tobago. In addition, we calculate the energy output of a BOREAS $30 \mathrm{~kW}$ small wind turbine using the $10 \mathrm{~m}$ level wind speed distribution extrapolated to hub height. The average air densities at Crown Point and Piarco were $1.156 \mathrm{~kg} \mathrm{~m}^{-3}$ and $1.159 \mathrm{~kg} \mathrm{~m}^{-3}$, respectively, and monthly air densities at both sites were at most $6 \%$ less than standard air density. The difference in energy output of the BOREAS $30 \mathrm{~kW}$ calculated using standard air density over that using the local site's air density could provide electrical energy for the continuous monthly operation of 6 light bulbs rated at $50 \mathrm{~W}$ at Crown Point and 4 light bulbs at Piarco. Thus, communities interested in implementing wind turbine technologies must use the local air density of the site when sizing a wind turbine system for its needs.
\end{abstract}

\section{Introduction}

The Fourth Assessment Report of the Intergovernmental Panel on Climate Change has recognized that small-island states are vulnerable to the effects of climate change, sea level rise, and extreme events [1]. Adverse stresses to coral and marine ecosystems, destruction of forested areas due to increases in cyclones or storms, reduced water supply and its impact on agriculture, reduced tourism due to coastal erosion, flooding, and increases in the incidence of vector-borne diseases have been projected with high confidence. Trinidad and Tobago, a twin small-island state located northeast of Venezuela in the Caribbean Sea, like other Caribbean islands, faces not only these potential climatic change impacts but also issues of energy security. Unlike most small-island states, Trinidad and Tobago is a net exporter of oil and gas. However, the increasing electricity demand [2] and carbon dioxide emissions [3], coupled with the 10-year lifetime of gas reserves [4], indicate a need to diversify the energy mix to include renewable energy (RE) sources for long-term sustainability
$[2,3]$. At present, wind energy is the most suitable source of renewable energy for bulk electricity generation in Trinidad and Tobago [2] and has the potential to reduce greenhouse gas emissions substantially [5]. In the 2010 budget allocations of the Republic of Trinidad and Tobago, tax incentives and programs were offered to assist in proliferating the use of renewable energy [6] including a wear and tear allowance and no import duties or value added tax on wind turbines.

An accurate assessment of the wind resource through meteorological measurements is required to take advantage of such incentives for small wind turbine generators for household electricity needs. The accuracy of the wind resource affects the energy output of a wind turbine [7]. The wind power density $P_{D}$, a measure of the wind resource, can be calculated from a wind speed time series consisting of $N$ wind speed measurements $v_{i}$ taken at equal time intervals via [8]

$$
P_{D}=\frac{1}{2 N} \sum_{i=1}^{N} \rho_{i} v_{i}^{3},
$$


where $\rho_{i}$ is the air density for the corresponding wind speed measurement $v_{i}$. It is well known that the accuracy of the wind power potential is highly dependent on wind speed because of the cubic dependence of wind potential on wind speed. However, communities intending to use wind turbine generators for their electricity needs may be unaware of the influence of air density on the power output of small wind turbines. Power curves of wind turbines provided by manufacturers are determined under standard air density conditions of $1.225 \mathrm{~kg} \mathrm{~m}^{-3}$ at temperature of $15^{\circ} \mathrm{C}$ and sea level pressure. However, the moist tropical maritime climates of the Caribbean islands have air densities that are less than standard air density due to the high atmospheric water vapor content. The air densities for moist tropical climates are not readily available because they are not directly measured nor straightforward to calculate. Even a 5\% difference in air density has significant effect on energy output for wind turbines [9]. Previous studies [10,11] have accounted for the influence of air density variations on energy output of a wind turbine by developing joint probability density function models for air density and wind speed to improve the estimation of energy output of a turbine. Bivariate statistical models may not be easily implemented by communities and homeowners who would more readily use constant air density values. While several studies have used local air density values in estimating wind turbine or wind farm energy output at locations such as Arar [12] and Dhulom [13] in Saudi Arabia, an offshore site in the Korean Peninsula [14], and the Mediterranean coast [15], they have not demonstrated how the use of local site air density versus the standard air density is related to household use.

In this study we determine the monthly air density for the moist tropical climate of Trinidad and Tobago and relate the difference in energy output when using standard air density over on-site air density to electrical lighting capabilities. Monthly local air densities are calculated to account for seasonal changes in the climate. The purpose of accurately assessing the air density is to determine the energy output of a wind turbine more precisely. This is to ensure that the public is provided with all relevant information including air density close to the surface, where the use of small wind turbines is relevant. Household end users would be better equipped to size wind turbines for their electricity needs when they fully understand how the air density affects the energy output of the wind turbine system. Although this paper focuses on the influence of air density on wind turbine output at a community scale, air density will have an even greater impact on the power output of large-scale wind farms. The public's understanding of factors affecting wind turbine output is critical for the development of a wind energy sector in Trinidad and Tobago.

\section{Data}

Hourly meteorological measurements are taken at only two long-term measurement sites in Trinidad and Tobago, namely, Piarco Airport in Trinidad and Crown Point Airport in Tobago. Air temperatures, dew-point temperatures,

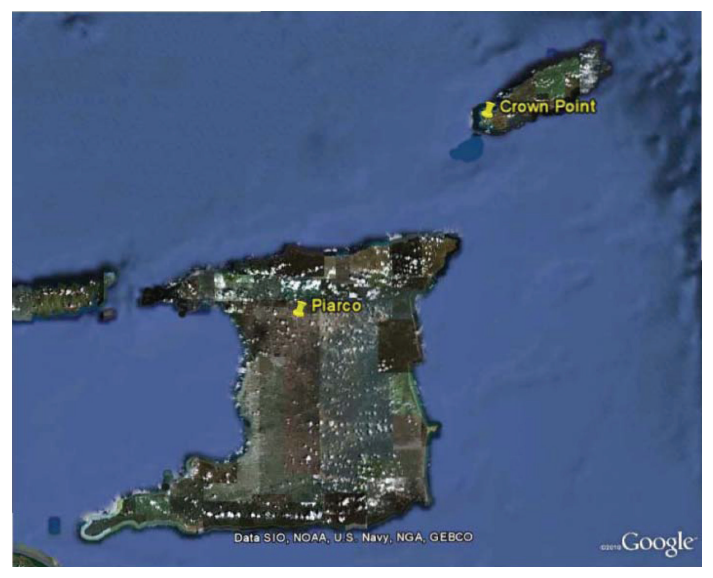

FIgURE 1: Map of Trinidad and Tobago showing the locations of the meteorological stations of Piarco and Crown Point. Stations are denoted by yellow pin markers. Source: Google Maps, 2011.

TABLE 1: Geographical locations and elevations of the measurement stations.

\begin{tabular}{lccc}
\hline Station name & Latitude (North) & Longitude (East) & $\begin{array}{c}\text { Elevation } \\
(\mathrm{m})\end{array}$ \\
\hline Piarco airport & +10.617 & -61.350 & +15.0 \\
Crown Point airport & +11.150 & -60.833 & +12.0 \\
\hline
\end{tabular}

and wind speeds for the 1989-2009 period are available through the USA National Climatic Data Center's website http://www.ncdc.noaa.gov/oa/ncdc.html. Crown Point station is located on the coast of the southwestern tip in Tobago while the Piarco station is an inland station in Trinidad. The locations of the two stations are shown in Figure 1, and the geographical locations are given in Table 1. The Meteorological Services of Trinidad and Tobago is responsible for the data collection, and observations are collected according to the World Meteorological Organization standards [16]. The data sets do not contain sea level pressures for each hour; therefore, monthly averages of sea level pressures were used to calculate the air density.

\section{Density of Moist Air}

Air density for moist air was calculated according to the formula CIPM-2007 endorsed by the International Committee of Weights and Measures [17]. The formula uses the air temperature and relative humidity which is derived from the dew-point temperature. The local air density $\rho_{l}$ is given by

$$
\rho_{l}=\frac{p M_{a}}{Z R\left(t_{a}+273.15\right)}\left[1-x_{v}\left(1-\frac{M_{v}}{M_{a}}\right)\right],
$$

where $p$ is the air pressure in Pascals, $t_{a}$ is the air temperature in degrees Celcius $\left({ }^{\circ} \mathrm{C}\right), M_{a}$ is the molar mass of dry air (= $\left.28.96546 \times 10^{-3} \mathrm{~kg} \mathrm{~mol}^{-1}\right), M_{v}$ is the molar mass of water vapor $\left(=18.01528 \times 10^{-3} \mathrm{~kg} \mathrm{~mol}^{-1}\right), R$ is the molar mass gas constant of dry air $\left(=8.314472 \mathrm{~J} \mathrm{~mol}^{-1} \mathrm{~K}^{-1}\right), Z$ is the compressibility factor of air, and $x_{v}$ is the mole fraction of 
water vapor in the air. The air pressure $p$ is provided by mean sea level pressures (SLPs) since the elevations of both sites, Crown Point and Piarco, are low, at most $15 \mathrm{~m}$ above sea level (Table 1).

The mole fraction, $x_{v}$, is given by

$$
x_{v}=f\left(p, t_{a}\right) \frac{H}{100} \frac{p_{\mathrm{sv}}\left(t_{a}\right)}{p} .
$$

In (3), $H$ is the relative humidity (\%), $p_{\text {sv }}$ is the saturation vapor pressure at air temperature $t_{a}$ and has units of Pascals, and $f$ is the enhancement factor and is nondimensional. If the dew-point temperature $t_{d}\left({ }^{\circ} \mathrm{C}\right)$ is available instead of the relative humidity, then $x_{v}$ is calculated from

$$
x_{v}=f\left(p, t_{d}\right) \frac{p_{\mathrm{sv}}\left(t_{d}\right)}{p} .
$$

Although the dew-point temperature could be used immediately into the formula, relative humidity was calculated first as a function of dew-point temperature in order to illustrate the variation in moisture content in the air throughout the year. Relative humidity was calculated from

$$
\mathrm{RH}(\%)=\exp \left[a b \frac{\left(t_{d}-t_{a}\right)}{\left(t_{d}+b\right)\left(t_{a}+b\right)}\right] \times 100,
$$

where $a=17.271$ and $b=237.7^{\circ} \mathrm{C}$. Equation (5) is a rearrangement of a formula by Lawrence [18] which relates dew-point temperature to relative humidity. $f$ and $p_{\text {sv }}$ in (3) may be estimated via

$$
\begin{gathered}
f=\alpha+\beta p+\gamma t_{a}^{2}, \\
p_{\mathrm{sv}}=1 \mathrm{~Pa} \times \exp \left[A\left(t_{a}+273.15\right)^{2}+B\left(t_{a}+273.15\right)\right. \\
\left.+C+\frac{D}{\left(t_{a}+273.15\right)}\right] .
\end{gathered}
$$

The air density equation, (2), also requires the compressibility factor of air, $Z$, which is given by [17]

$$
\begin{array}{r}
Z=1-\frac{p}{\left(t_{a}+273.15\right)}\left[a_{0}+a_{1} t_{a}+a_{2} t_{a}^{2}\right. \\
+\left(b_{0}+b_{1} t_{a}\right) x_{v} \\
\left.+\left(c_{0}+c_{1} t_{a}\right) x_{v}^{2}\right] \\
+\frac{p^{2}}{\left(t_{a}+273.15\right)^{2}}\left[d+e x_{v}^{2}\right] .
\end{array}
$$

The constants in (6), (7), and (8) are provided in the appendix.

\section{Energy Output of a Small Wind Turbine}

We considered the energy output of a BOREAS wind turbine of rated power $30 \mathrm{~kW}$ to demonstrate the influence of air density. We chose this wind turbine since its hub height is $z_{h}=25 \mathrm{~m}$ and it is of a reasonable size for household use. The BOREAS $30 \mathrm{~kW}$ has a cut-in wind speed $\left(u_{c}\right)$ of $3 \mathrm{~m} / \mathrm{s}$, rated wind speed $\left(u_{r}\right)$ of $9 \mathrm{~m} / \mathrm{s}$, a cut-out wind speed $\left(u_{f}\right)$ of $25 \mathrm{~m} / \mathrm{s}$, and rotor diameter of $14 \mathrm{~m}$ [8]. The capacity factor of this wind turbine under the wind regime of the sites considered is given by [19]

$$
c_{F}=\frac{\exp \left[-\left(u_{c} / c\right)^{k}\right]-\exp \left[-\left(u_{r} / c\right)^{k}\right]}{\left(u_{r} / c\right)^{k}-\left(u_{c} / c\right)^{k}}-\exp \left[-\left(\frac{u_{f}}{c}\right)^{k}\right],
$$

where we have assumed that the wind speed distribution can be modeled by a Weibull probability density function (pdf) which is defined by a scale parameter $c$ and a shape parameter $k$. Estimates of mean monthly wind speeds, standard deviations in wind speeds in each month, and monthly wind power density estimates using the Weibull pdf have been found to have a high correlation with the corresponding statistics derived from the hourly wind speed measurements. In the absence of wind speed measurements at multiple vertical levels, we estimated monthly Weibull parameters at hub height using the empirical relations described by (10) and monthly Weibull parameters derived from the $10 \mathrm{~m}$ level wind speed measurements [20-22].

Consider

$$
\begin{gathered}
k_{h}=k_{10}\left\{1-0.0881 \times \ln \left(\frac{z_{h}}{10}\right)\right\}^{-1}, \\
c_{h}=c_{10} \times\left(\frac{z_{h}}{10}\right)^{n}, \\
n=0.37-0.0881 \times \ln \left(c_{10}\right) .
\end{gathered}
$$

These empirical relations assume that the wind speed increases according to a power law. The power law exponent is dependent on wind speed, and the maximum height to which wind speeds could be extrapolated is $100 \mathrm{~m} \mathrm{[21].} \mathrm{We} \mathrm{also} \mathrm{note}$ that these empirical relations were derived from wind shear measurements obtained from four midlatitude locations in the United States of America [21]. Similar relations for tropical locations can be developed as wind data at greater heights become available.

The average power output of the wind turbine $P_{\text {Ave }}$ was calculated using [19]

$$
P_{\text {Ave }}=c_{F} P_{R}
$$

where $P_{R}$ is the rated power of the wind turbine. The energy output $E$ of the wind turbine in $T$ hours $(\mathrm{kWh})$ was then determined via

$$
E=P_{\text {Ave }} \times T
$$

For each month, $T$ is assumed to be 720 hours (30 days).

The energy output when the standard air density $\rho_{s}$ is used instead of the local air density was found by a simple scaling [23]. 


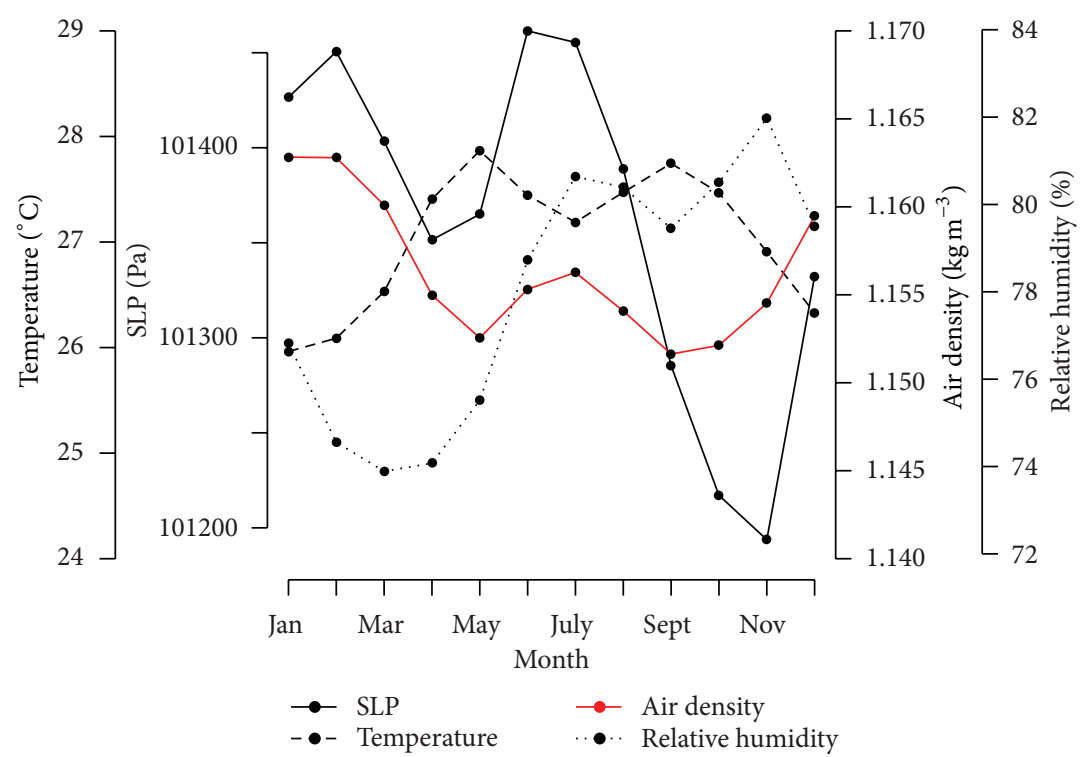

(a)

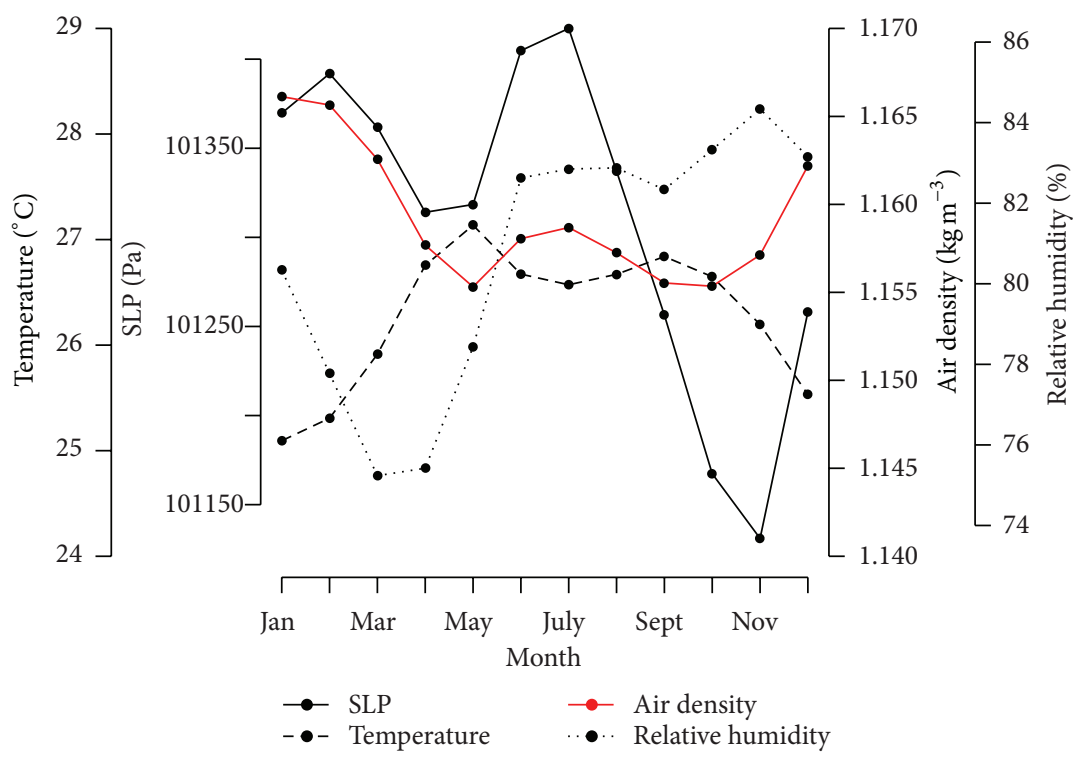

(b)

Figure 2: Monthly averaged air temperatures, sea level pressures, relative humidities, and air densities at (a) Crown Point and (b) Piarco.

Consider

$$
E_{(z) m, \rho_{s}}=\frac{\rho_{s}}{\rho_{l}} E_{(z) m, \rho_{l}},
$$

where $\rho_{s}$ is standard air density of $1.225 \mathrm{~kg} \mathrm{~m}^{-3}$ at temperature of $15^{\circ} \mathrm{C}$ and sea level pressure, and $\rho_{l}$ is the monthly air density at the local sites. This scaling is applicable because the air density is considered to be a constant meteorological parameter within each month.

\section{Results and Discussion}

The monthly variations in sea level pressure, air temperature, relative humidity, and the calculated air density at Crown
Point and Piarco are shown in Figure 2. At Crown Point, atmospheric humidity ranges from a minimum of $74 \%$ in March to $82 \%$ in November. The monthly air density had minima in May and September with a value of approximately $1.152 \mathrm{~kg} \mathrm{~m}^{-3}$ (Table 2) and a maximum in January of $1.162 \mathrm{~kg} \mathrm{~m}^{-3}$. The annual average air density at Crown Point was $1.156 \mathrm{~kg} \mathrm{~m}^{-3}$, which is $5.6 \%$ less than the standard air density of $1.225 \mathrm{~kg} \mathrm{~m}^{-3}$.

Relative humidity at Piarco is slightly greater than that at Crown Point and varies from approximately $75 \%$ in March to $84 \%$ in November. The main difference between the Piarco and Crown Point stations lies in the range of sea level pressures; Piarco generally experienced lower sea level 
Table 2: Monthly air densities at Crown Point and Piarco.

\begin{tabular}{|c|c|c|c|c|}
\hline Month & $\begin{array}{l}\text { Crown Point air } \\
\text { density }\left(\mathrm{kg} \mathrm{m}^{-3}\right)\end{array}$ & $\begin{array}{l}\text { Percentage offset to the } \\
\text { standard air density }\end{array}$ & $\begin{array}{c}\text { Piarco air } \\
\text { density }\left(\mathrm{kg} \mathrm{m}^{-3}\right)\end{array}$ & $\begin{array}{c}\text { Percentage offset to the } \\
\text { standard air density }\end{array}$ \\
\hline January & 1.163 & -5.08 & 1.166 & -4.81 \\
\hline February & 1.163 & -5.08 & 1.165 & -4.84 \\
\hline March & 1.160 & -5.29 & 1.163 & -5.10 \\
\hline April & 1.155 & -5.72 & 1.158 & -5.50 \\
\hline May & 1.153 & -5.91 & 1.155 & -5.69 \\
\hline June & 1.155 & -5.69 & 1.158 & -5.47 \\
\hline July & 1.156 & -5.61 & 1.159 & -5.41 \\
\hline August & 1.154 & -5.79 & 1.157 & -5.53 \\
\hline September & 1.152 & -5.99 & 1.156 & -5.67 \\
\hline October & 1.152 & -5.95 & 1.155 & -5.69 \\
\hline November & 1.155 & -5.75 & 1.157 & -5.54 \\
\hline December & 1.159 & -5.35 & 1.162 & -5.13 \\
\hline
\end{tabular}

TABLE 3: Estimated shape and scale parameters at hub height, capacity factor, energy output of turbine considered under standard air density conditions and under local site's air density conditions, difference in energy output when the local site's air density conditions are considered in comparison to energy output using standard air density, and lighting equivalent to this energy output difference at Crown Point.

\begin{tabular}{|c|c|c|c|c|c|c|c|}
\hline Month & $\begin{array}{c}c \text { at } 25 \mathrm{~m} \text { level } \\
\left(\mathrm{ms}^{-1}\right)\end{array}$ & $\begin{array}{c}k \text { at } 25 \mathrm{~m} \\
\text { level }\end{array}$ & $c_{p}$ & $\begin{array}{l}E_{25 \mathrm{~m}, \rho_{l}} \\
(\mathrm{kWh})\end{array}$ & $\begin{array}{l}E_{25 \mathrm{~m}, \rho_{s}} \\
(\mathrm{kWh})\end{array}$ & $\begin{array}{c}E_{25 \mathrm{~m}, \rho_{l}}-E_{25 \mathrm{~m}, \rho_{s}} \\
(\mathrm{kWh})\end{array}$ & $\begin{array}{c}\text { Lighting equivalent to the difference } \\
E_{25 \mathrm{~m}, \rho_{l}}-E_{25 \mathrm{~m}, \rho_{s}} \text { in terms of the number } \\
\text { of } 50 \mathrm{~W} \text { light bulbs operating for } 720 \\
\text { hours }\end{array}$ \\
\hline January & 4.92 & 1.86 & 0.23 & 5039.96 & 4784.16 & -255.80 & 7 lights \\
\hline February & 5.33 & 1.93 & 0.27 & 5859.81 & 5562.24 & -297.57 & 7 lights \\
\hline March & 5.47 & 1.93 & 0.28 & 6156.80 & 5830.61 & -326.19 & 8 lights \\
\hline April & 5.96 & 2.17 & 0.32 & 6922.05 & 6526.42 & -395.63 & 10 lights \\
\hline May & 6.21 & 2.36 & 0.33 & 7243.55 & 6815.16 & -428.39 & 11 lights \\
\hline June & 5.90 & 2.30 & 0.30 & 6561.17 & 6187.95 & -373.22 & 9 lights \\
\hline July & 4.99 & 1.88 & 0.23 & 5159.32 & 4869.85 & -289.48 & 8 lights \\
\hline August & 4.58 & 1.84 & 0.20 & 4303.29 & 4054.16 & -249.13 & 6 lights \\
\hline September & 4.81 & 1.97 & 0.21 & 4557.16 & 4284.22 & -272.95 & 7 lights \\
\hline October & 4.73 & 1.91 & 0.20 & 4499.70 & 4232.02 & -267.68 & 7 lights \\
\hline November & 4.59 & 1.82 & 0.20 & 4377.18 & 4125.33 & -251.85 & 6 lights \\
\hline December & 4.72 & 1.83 & 0.21 & 4659.66 & 4410.41 & -249.25 & 6 lights \\
\hline
\end{tabular}

pressures with maximum occurring in July while at Crown Point the maximum occurred in June. Piarco's minimum and maximum monthly air densities were $1.155 \mathrm{~kg} \mathrm{~m}^{-3}$ and $1.166 \mathrm{~kg} \mathrm{~m}^{-3}$, respectively. At Piarco, air density minima and maxima were in the same months as those at Crown Point. The annual mean air density at Piarco was $1.159 \mathrm{~kg} \mathrm{~m}^{-3}, 5.4 \%$ less than standard air density.

Table 2 shows the air density values for each month and the percentage difference of each month's air density from the standard air density of $1.225 \mathrm{~kg} \mathrm{~m}^{-3}$. Monthly air density at each site is at most $6 \%$ less than the standard air density. Since wind power density is a linear function of air density, a $6 \%$ change in air density will result in a $6 \%$ change in wind power density.

Tables 3 and 4 show the Weibull parameters $c$ and $k$ at the $25 \mathrm{~m} \mathrm{level,} \mathrm{the} \mathrm{capacity} \mathrm{factor,} \mathrm{and} \mathrm{energy} \mathrm{output}$ of the BOREAS $30 \mathrm{~kW}$ wind turbine at Crown Point and Piarco, respectively. The energy outputs were calculated using monthly air densities for the local sites (Table 2) and standard air density. The scale and shape parameters at hub height have maxima in May at Crown Point and in April at Piarco. The capacity factor at Crown Point (Table 3 ) is greater than that at Piarco (Table 4) indicating that the BOREAS $30 \mathrm{~kW}$ wind turbine is better suited to the wind regime at Crown Point than Piarco for electricity generation. Also shown in the last two columns of Tables 3 and 4 are the differences in energy output using standard air density compared with the energy output calculated with the site's local air density and energy difference in an equivalent form of number of lights with power rating of $50 \mathrm{~W}$ operating over an entire month of 720 hours.

The wind turbine energy output is overestimated when standard air density conditions are used instead of the local 
TABLE 4: Estimated shape and scale parameters at hub height, capacity factor, energy output of turbine considered under standard air density conditions and under local site's air density conditions, difference in energy output when the local site's air density conditions are considered in comparison to energy output using standard air density, and lighting equivalent to this energy output difference at Piarco.

\begin{tabular}{|c|c|c|c|c|c|c|c|}
\hline Month & $\begin{array}{c}c \text { at } 25 \mathrm{~m} \text { level } \\
\qquad\left(\mathrm{ms}^{-1}\right)\end{array}$ & $\begin{array}{c}k \text { at } 25 \mathrm{~m} \\
\text { level }\end{array}$ & $c_{p}$ & $\begin{array}{l}E_{25 \mathrm{~m}, \rho_{l}} \\
(\mathrm{kWh})\end{array}$ & $\begin{array}{l}E_{25 \mathrm{~m}, \rho_{s}} \\
(\mathrm{kWh})\end{array}$ & $\begin{array}{c}E_{25 \mathrm{~m}, \rho_{l}}-E_{25 \mathrm{~m}, \rho_{s}} \\
(\mathrm{kWh})\end{array}$ & $\begin{array}{l}\text { Lighting equivalent to the difference } \\
E_{25 \mathrm{~m}, \rho_{l}}-E_{25 \mathrm{~m}, \rho_{s}} \text { in terms of the number } \\
\text { of } 50 \mathrm{~W} \text { light bulbs operating for } 720 \\
\text { hours }\end{array}$ \\
\hline January & 4.44 & 1.54 & 0.21 & 4706.50 & 4480.30 & -226.20 & 6 lights \\
\hline February & 4.81 & 1.59 & 0.24 & 5381.54 & 5120.80 & -260.74 & 7 lights \\
\hline March & 4.94 & 1.63 & 0.25 & 5568.26 & 5284.65 & -283.81 & 7 lights \\
\hline April & 5.12 & 1.76 & 0.26 & 5707.96 & 5394.30 & -313.67 & 8 lights \\
\hline May & 5.04 & 1.75 & 0.25 & 5546.69 & 5231.15 & -315.54 & 8 lights \\
\hline June & 4.77 & 1.70 & 0.23 & 5051.08 & 4773.04 & -276.04 & 7 lights \\
\hline July & 4.12 & 1.57 & 0.18 & 3945.71 & 3732.11 & -213.60 & 5 lights \\
\hline August & 3.59 & 1.53 & 0.13 & 2932.91 & 2770.69 & -162.21 & 4 lights \\
\hline September & 3.61 & 1.60 & 0.12 & 2780.84 & 2623.14 & -157.70 & 4 lights \\
\hline October & 3.63 & 1.59 & 0.13 & 2851.84 & 2689.69 & -162.15 & 4 lights \\
\hline November & 3.70 & 1.57 & 0.14 & 3049.71 & 2880.73 & -168.98 & 4 lights \\
\hline December & 4.07 & 1.53 & 0.18 & 3933.85 & 3732.14 & -201.71 & 5 lights \\
\hline
\end{tabular}

site's air density. The projections in monthly energy output of the wind turbine using standard air density exceed those projections using local site's air density by 251 to $428 \mathrm{~kW} \mathrm{~h}$ at Crown Point and 157 to $315 \mathrm{~kW}$ h at Piarco. These overestimations in monthly energy output are equivalent to the lighting provided by 6 to 11 light bulbs rated at $50 \mathrm{~W}$ at Crown Point and 4 to 8 light bulbs at Piarco. Therefore, if the BOREAS $30 \mathrm{~kW}$ wind turbine was selected for Crown Point and Piarco using standard air density in the energy projections, then the wind turbine will not be able to power a minimum of 6 light bulbs at Crown Point and a minimum of 4 light bulbs at Piarco throughout the year when operating under local air density conditions. Thus, the wind turbine would not be able to provide the electric lighting needs for one rural home when operating under the local site's air density conditions rather than standard air density conditions. The use of standard air density instead of local air density could misjudge the number of homes that communities could power from the wind.

\section{Conclusions}

In this study, we have calculated the monthly air densities at two sites under moist tropical conditions in the islands of Trinidad and Tobago. Furthermore, with the use of a BOREAS $30 \mathrm{~kW}$ small wind turbine, we have demonstrated that there are overestimations in monthly energy output using standard air density rather than the air density conditions of the local site. This may lead to approximately one rural home not having electric lighting. Customers who have been disappointed by the energy output of wind energy technologies could influence the development of a new wind energy sector because of unmet expectations. It is critical that household end users are informed on all factors influencing the wind resource and the energy output of wind turbines.
Accounting for local air density will be crucial when scaling the application to large wind turbine output which could provide electricity for several villages and communities. Wind energy technologies would fail to provide the very service for which they are commissioned.

\section{Appendix}

The constants in (6), (7), and (8) are as follows [17]:

$$
\begin{gathered}
\alpha=1.00062, \\
\beta=3.14 \times 10^{-8} \mathrm{~Pa}^{-1}, \\
\gamma=5.6 \times 10^{-7} \mathrm{~K}^{-2}, \\
A=1.2378847 \times 10^{-5} \mathrm{~K}^{-2}, \\
B=-1.9121316 \times 10^{-2} \mathrm{~K}^{-1}, \\
C=33.93711047, \\
D=-6.3431645 \times 10^{3} \mathrm{~K}, \\
a_{0}=1.58123 \times 10^{-6} \mathrm{~K} \mathrm{~Pa}^{-1}, \\
a_{1}=-2.9331 \times 10^{-8} \mathrm{~Pa}^{-1}, \\
a_{2}=1.1043 \times 10^{-10} \mathrm{~K}^{-1} \mathrm{~Pa}^{-1}, \\
b_{0}=5.707 \times 10^{-6} \mathrm{~K} \mathrm{~Pa}^{-1}, \\
b_{1}=-2.051 \times 10^{-8} \mathrm{~Pa}^{-1}, \\
c_{0}=1.9898 \times 10^{-4} \mathrm{~K} \mathrm{~Pa}^{-1}, \\
c_{1}=-2.376 \times 10^{-6} \mathrm{~Pa}^{-1},
\end{gathered}
$$




$$
\begin{aligned}
& d=1.83 \times 10^{-11} \mathrm{~K}^{2} \mathrm{~Pa}^{-2}, \\
& e=-0.765 \times 10^{-8} \mathrm{~K}^{2} \mathrm{~Pa}^{-2} .
\end{aligned}
$$

\section{Conflict of Interests}

The authors declare that there is no conflict of interests regarding the publication of this paper.

\section{References}

[1] IPCC, Climate Change 2007-Impacts, Adaptation and Vulnerability. Contributions of Working Group II to the Fourth Assessment Report of the Intergovernmental Panel on Climate Change, Cambridge University Press, Cambridge, UK, 2007.

[2] Ministry of Energy and Energy Affairs, Framework for Development of a Renewable Energy Policy for Trinidad and Tobago, Ministry of Energy and Energy Affairs, Port of Spain, Trinidad and Tobago, 2011.

[3] Government of Trinidad and Tobago, National Climate Change Policy, Ministry of Housing and Environment, Port of Spain, Trinidad and Tobago, 2011.

[4] R. Singh, “Ten years left,” Trinidad Express Newspapers, 2010, http://www.trinidadexpress.com/news/98392284.html.

[5] IPCC, "Summary for policymakers," in IPCC Special Report on Renewable Energy Sources and Climate Change Mitigation, O. Edenhofer, R. Pichs-Madruga, Y. Sokona, K. Seyboth, P. Matschoss, and S. Kadner, Eds., Cambridge University Press, Cambridge, UK, 2011.

[6] Government of The Republic of Trinidad and Tobago, "Budget Statement 2011," 2010, http://www.finance.gov.tt/publications.php? $\mathrm{mid}=192$.

[7] J. K. Kaldellis, "Optimum autonomous wind-power system sizing for remote consumers, using long-term wind speed data," Applied Energy, vol. 71, no. 3, pp. 215-233, 2002.

[8] D. Karamanis, "Management of moderate wind energy coastal resources," Energy Conversion and Management, vol. 52, no. 7, pp. 2623-2628, 2011.

[9] P. Gipe, Wind Power: Renewable Energy for Home, Farm, and Busines, Chelsea Green Publishing Company, White River Junction, Vt, USA, 2008.

[10] J. A. Carta and D. Mentado, "A continuous bivariate model for wind power density and wind turbine energy output estimations," Energy Conversion and Management, vol. 48, no. 2, pp. 420-432, 2007.

[11] X. Qu and J. Shi, "Bivariate modeling of wind speed and air density distribution for long-term wind energy estimation," International Journal of Green Energy, vol. 7, no. 1, pp. 21-37, 2010.

[12] S. Rehman and N. M. Al-Abbadi, "Wind shear coefficients and their effect on energy production," Energy Conversion and Management, vol. 46, no. 15-16, pp. 2578-2591, 2005.

[13] S. Rehman and N. M. Al-Abbadi, "Wind shear coefficient, turbulence intensity and wind power potential assessment for Dhulom, Saudi Arabia," Renewable Energy, vol. 33, no. 12, pp. 2653-2660, 2008.

[14] K. Y. Oh, J. Y. Kim, J. K. Lee, M. S. Ryu, and J. S. Lee, "An assessment of wind energy potential at the demonstration offshore wind farm in Korea," Energy, vol. 46, pp. 555-563, 2012.
[15] A. S. Ahmed Shata and R. Hanitsch, "Evaluation of wind energy potential and electricity generation on the coast of Mediterranean Sea in Egypt," Renewable Energy, vol. 31, no. 8, pp. 1183-1202, 2006.

[16] World Meteorological Organization, Guide to Meteorological Instruments and Methods of Observation, World Meteorological Organization, Geneva, Switzerland, 7th edition, 2008.

[17] A. Picard, R. S. Davis, M. Gläser, and K. Fujii, "Revised formula for the density of moist air (CIPM-2007)," Metrologia, vol. 45, no. 2, pp. 149-155, 2008.

[18] M. G. Lawrence, “The relationship between relative humidity and the dewpoint temperature in moist air: a simple conversion and applications," Bulletin of the American Meteorological Society, vol. 86, no. 2, pp. 225-233, 2005.

[19] A. M. Eltamaly, "Design and implementation of wind energy system in Saudi Arabia," Renewable Energy, vol. 60, pp. 42-52, 2013.

[20] A. M. Eltamaly and H. M. Farh, "Wind energy assessment for five locations in Saudi Arabia," Journal of Renewable and Sustainable Energy, vol. 4, no. 2, Article ID 022702, 2012.

[21] C. G. Justus and A. Mikhail, "Height variation of wind speed and wind distributions statistics," Geophysical Research Letters, vol. 3, no. 5, pp. 261-264, 1976.

[22] G. Gualtieri and S. Secci, "Methods to extrapolate wind resource to the turbine hub height based on power law: a 1-h wind speed vs. Weibull distribution extrapolation comparison," Renewable Energy, vol. 43, pp. 183-200, 2012.

[23] A. W. Dahmouni, M. Ben Salah, F. Askri, C. Kerkeni, and S. Ben Nasrallah, "Assessment of wind energy potential and optimal electricity generation in Borj-Cedria, Tunisia," Renewable and Sustainable Energy Reviews, vol. 15, no. 1, pp. 815-820, 2011. 


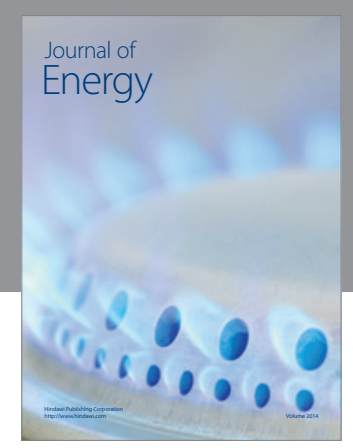

Journal of

Industrial Engineering


Fuels


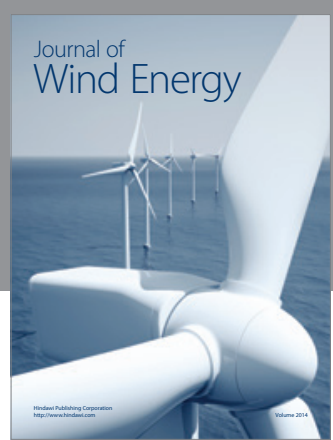

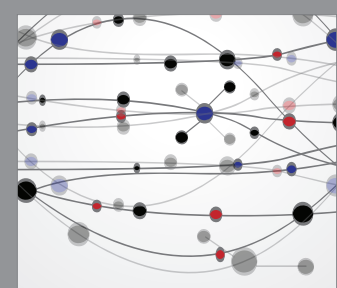

The Scientific World Journal

Submit your manuscripts at http://www.hindawi.com

Journal of

Structures


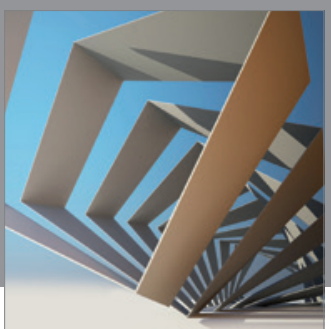

Rotating

Machinery
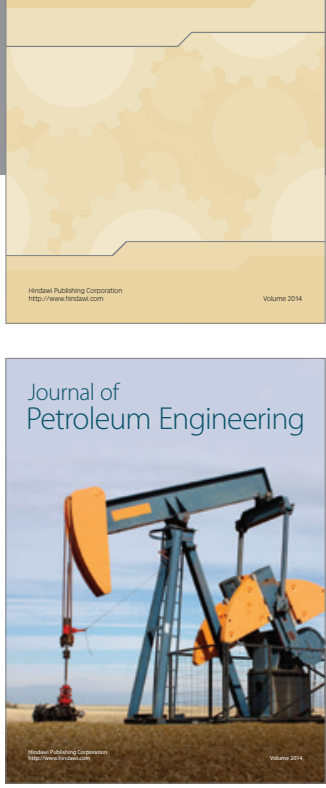

Journal of

Solar Energy
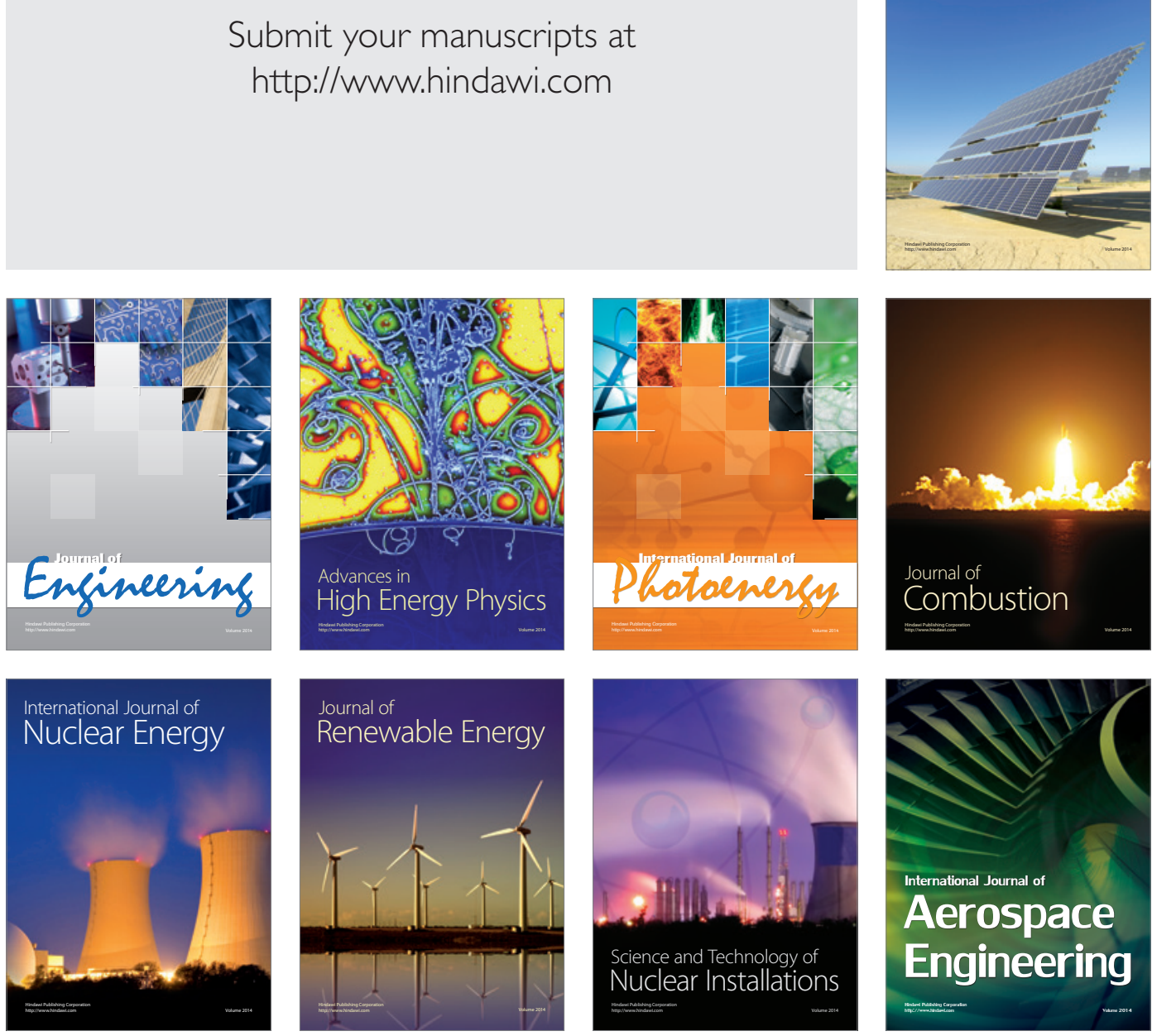